\title{
Multivariate statistical evaluation of heavy metals in the surface water sources of Jia Bharali river basin, North Brahmaputra plain, India
}

\author{
Nayan J. Khound ${ }^{1} \cdot$ Krishna G. Bhattacharyya $^{2}$
}

Received: 21 November 2015/Accepted: 21 July 2016/Published online: 13 August 2016

(c) The Author(s) 2016. This article is published with open access at Springerlink.com

\begin{abstract}
The aim of this study was to assess the quality of surfacewater sources in the Jia Bharali river basin and adjoining areas of the Himalayan foothills with respect to heavy elements viz. (As, $\mathrm{Cd}, \mathrm{Cr}, \mathrm{Cu}, \mathrm{Fe}, \mathrm{Mn}, \mathrm{Ni}, \mathrm{Pb}$ and $\mathrm{Zn})$ by hydrochemical and multivariate statistical techniques, such as cluster analysis (CA) and principal component analysis (PCA). This study presents the first ever systematic analysis on toxic elements of water samples collected from 35 different surface water sources in both the dry and wet seasons for a duration of 2 hydrological years (2009-2011). Varimax factors extracted by principal component analysis indicates anthropogenic (domestic and agricultural run-off) and geogenic influences on the trace elements. Hierarchical cluster analysis grouped 35 surfacewater sources into three statistically significant clusters based on the similarity of water quality characteristics. This study illustrates the usefulness of multivariate statistical techniques for analysis and interpretation of complex data sets, and in water quality assessment, identification of pollution sources/factors and understanding temporal/spatial variations in water quality for effective surfacewater quality management.
\end{abstract}

Keywords Heavy metals - Principal component . Hierarchical cluster - Brahmaputra plain - Surfacewater source $\cdot$ Jia Bharali river basin

Nayan J. Khound

njkhound@gmail.com

Department of Chemistry, Digboi College, Tinsukia, India

2 Department of Chemistry, Gauhati University, Guwahati, India

\section{Introduction}

Trace metals attributing as common pollutants are found to be widely distributed in the river catchments originating from natural sources and processes as chemical weathering, soil erosion, fallout of aerosols from marine, volcanic or arid soil sources. However, as a result of human inputs and activities (Merian 1991) the level of these metals in the environment has increased tremendously. Due to simplicity the univariate statistical analysis has been generally used to treat trace element data in groundwater (Helena et al. 2000). However, multivariate analysis such as principle component analysis (PCA) and cluster analysis is widely used to explain the correlation amongst a large number of variables in terms of a small number of underlying factors without losing much information (Meglen 1992; Ogwoeleka 2015; Pazand 2016; Qian et al. 2016). This method can also help in measuring natural associations between samples and/or variables (Wenning and Erickson 1994) and thus highlight the information which is not available at first glance.

For this study, lower Jia Bharali catchment and adjoining areas in central part of North Brahmaputra Plain (NBP) was selected which is characterized by more than $800 \mathrm{~m}$ thick older and younger Alluvium deposited by the west flowing Brahmaputra river and the south flowing trans Himalayan rivers (Khound Nayan et al. 2013). The river regime is highly dynamic with frequent channel changes and copious sand deposition. Average sediment load carried by these rivers are coarse, facilitating easy percolation and recharge of groundwater regime. Published reports (Chakrapani 2005; Singh et al. 2005; Jameel and Hussain 2007) reveal that most of the Indian rivers are carriers of untreated sewage, industrial effluent and runoff from agricultural and urban land to the surface water bodies present in their basins. Due to the absence of industrial 
zone and large scale irrigation projects the surface and ground water regime of the study area are expected to be free from such condition and bear a pristine signature of the natural environment. The people in the Jia Bharali river basin seldom use the surface water for drinking as well as for various household purposes including irrigation of crops, rearing of poultry and fish, etc. The population of the basin mainly consists of farmers and fishermen who depend on the surface water sources for their livelihood. In this context, the major objectives of this study were to (1) determine natural associations between surfacewater samples and metallic variables; (2) investigate the spatial and temporal variation of trace metal composition of the surfacewater sources and, (3) demonstrate the usefulness of the statistical analysis to interpret the trace element composition of the surfacewater sources of Jia Bharali river basin.

\section{Materials and methods}

\section{Study area}

The Jia Bharali catchment is bounded by longitudes $92^{\circ} 00 /-93^{\circ} 25 / \mathrm{E}$ and latitudes $26^{\circ} 39 /-28^{\circ} 00 / \mathrm{N}$. The drainage system of north Brahmaputra plain, N E India is made up of a large number of river systems flowing from Arunachal Himalaya in the north and debouching into the Brahmaputra in the south. It is an actively subsiding foreland basin with river regime bearing neotectonic changes and catchment area tectonics (Phukon and Machahary 2011). The precursor trunk channel of the Jia Bharali, known as the Kameng, flows orthogonal to the Himalayan thrust pattern and deflects along the Tipi Thrust in the north and the foothills fault in the south, respectively, before debouching into the foreland at Bhalukpung $\left(92^{\circ} 65 /\right.$ E, $27^{\circ} 01 / \mathrm{N}$ ). Further downstream, the River is known as the Bharali with its catchment localized within the Brahmaputra alluvium. The major tributaries of Jia Bharali are the Diju, Namiri, Upar Dikrai, Khari Dikrai, and Bor Dikrai coming from the foothills on the left bank and the Mansiri with numerous feeders from the Balipara hills on the right bank. The Jia Bharali river has water yield of 85.8 litre per second $/ \mathrm{km}^{2}$ and sediment yield of 4721 tons $\mathrm{km}^{2}$ / year (Goswami 1985; Viswanathan and Chakrabarti 1977). The geomorphic mapping of the alluvial catchment has revealed the presence of a number of river terraces at different topographic levels with the present Jia Bharali (Jia meaning alive in local language) channel system occupying the lowest level. Older Alluvium is found to be composed of partially indurated and oxidized sand, silt and clay form higher topographic levels in the study area which are found dotting the landscape within an overall younger alluvial terrane of present day river deposits. The higher topographic surfaces are used for extensive tea-plantations while the lower ones are mostly used for paddy cultivation. The climate of the study area is sub-tropical in nature with hot and humid summer, (average temperature $29^{\circ} \mathrm{C}$ ), heavy monsoon rain (May-September) followed by inundation of almost the entire area, dry autumn and cold winter (November-February, average temperature $16{ }^{\circ} \mathrm{C}$ ) (Jain et al. 2007). Rainfall during July and August is the highest and amounts to more than $33 \%$ of the annual rainfall. Depending on the prevailing climate and influence on different winds mainly monsoon, the basin experiences the highest rainfall during June-September with average rainfall $\sim 1500-2000 \mathrm{~mm}$ (Jain et al. 2007). The rock types encountered in Jia Bharali river basin are successively the Siwaliks (Tertiaries), Gondwanas, and Precambrian Bichom Group, Tenga Formation, Bomdila Group and Sela Group (Nandy et al. 1971). The drainage network of the Jia Bharali river is a rectangular drainage in the western part of the basin where the main streams and their tributaries display right-angled bends (Thornbury 1989). The eastern part of the catchment is made up of dendritic drainage with tectonically inactive terrain (Ahmed 2001). All the major streams and the rivers in this part of the catchment follow the structural trends of the Himalayas. The area is almost free from industrial activities and agriculture is the main economic activity within the basin. Thus, studied surfacewater sources receive a large amount of agricultural runoff and untreated domestic waste water from the basin.

\section{Water sampling and chemical analysis}

Water samples from 35 surface water sources consisting of small streams, rivers, and ponds spread over the entire area of the Jia Bharali river basin are collected from pre-selected locations twice a year (wet and dry seasons) for a two year period from 2009 to 2011 . The sampling programme is conducted as (1) W1: wet season (July 2009) (2) W2: wet season (July 2010) (3) D1: dry season (February 2010) (4) D2: dry season (February 2011). Thus, sampling and analysis process includes 35 surfacewater sources and four seasons (two wet and two dry seasons) for the entire study period. Standard methods (APHA and AWWA (American Public Health Association) 1998) are followed in collection, storage and analysis of the water samples. The metals are estimated in an Atomic Absorption Spectrometer (Varian SpectrAA 220) following standard acid digestion technique and the results are further verified for accuracy by analyzing a few random samples in the ICPMS. Statistical analysis is carried out using statistical 
package for social sciences (SPSS Version16) (Pazand 2016; Qian et al. 2016).

\section{Results and discussion}

\section{Spatial and temporal variations of the trace metals}

In this study, arsenic concentration of the surface water samples is in the range of BDL to $0.003 \mathrm{mg} / \mathrm{L}$ (mean $0.001 \mathrm{mg} / \mathrm{L}$ ) in all the wet seasons and from BDL to $0.008 \mathrm{mg} / \mathrm{L}$ (mean $0.001 \mathrm{mg} / \mathrm{L}$ ) in all the dry seasons. All of the values are below the recommended maximum permissible limit of drinking water standards $(0.01 \mathrm{mg} / \mathrm{L}$, WHO 1984). Cd content of the surface water sources varies from BDL to $0.015 \mathrm{mg} / \mathrm{L}$ (mean $0.003 \mathrm{mg} / \mathrm{L}$ ) in the wet seasons and from BDL to $0.041 \mathrm{mg} / \mathrm{L}$ (mean $0.008 \mathrm{mg} / \mathrm{L}$ ) in the dry seasons. However, $20.1 \%$ of the samples in the rainy season and $34.4 \%$ of the samples in the dry season have cadmium content higher than the desirable limit of $0.005 \mathrm{mg} / \mathrm{L}$ (WHO 1984). The distribution of $\mathrm{Cd}$ in the surface water is relatively consistent throughout the study area, implying that it could have been derived from nonpoint sources such as agricultural runoff. The cobalt contents of the surface water sources in the study area are in the ranges of BDL to $0.061 \mathrm{mg} / \mathrm{L}$ with a mean value of $0.018 \mathrm{mg} / \mathrm{L}$ in the wet seasons and from BDL to $0.106 \mathrm{mg} /$ $\mathrm{L}$ with a mean value of $0.04 \mathrm{mg} / \mathrm{L}$ in the dry seasons. WHO (2004) has not proposed any drinking water guideline value for $\mathrm{Co}$, but the values in the present work appear considerable. In this study, the copper concentration of the water samples is found far below the desirable value of $2 \mathrm{mg} / \mathrm{L}$ (WHO 1984). Copper content of the surface water samples ranges from BDL to $0.20 \mathrm{mg} / \mathrm{L}$ (mean $0.04 \mathrm{mg} / \mathrm{L}$ ) in the wet seasons and BDL to $0.21 \mathrm{mg} / \mathrm{L}$ (mean $0.10 \mathrm{mg} /$ $\mathrm{L}$ ) in the dry seasons. In this work, the total $\mathrm{Cr}$ concentration [both $\mathrm{Cr}(\mathrm{III})$ and $\mathrm{Cr}(\mathrm{VI})$ ] varied from low to sufficiently high values, i.e., from 0.02 to $0.43 \mathrm{mg} / \mathrm{L}$ (mean $0.13 \mathrm{mg} / \mathrm{L}$ ) in the dry seasons and from BDL to $0.19 \mathrm{mg} / \mathrm{L}$ (mean $0.07 \mathrm{mg} / \mathrm{L}$ ) in the wet seasons. $94.4 \%$ of the surface water sources show more $\mathrm{Cr}$ concentration in the dry season. WHO (2004) has suggested a maximum permissible value of $0.05 \mathrm{mg} / \mathrm{L}$ for $\mathrm{Cr}$ in drinking water and most of the sources in the studied area have $\mathrm{Cr}$ exceeding this value. So, it is clear that most of the surfacewater sources of the study area had high $\mathrm{Cr}$ content in both the wet and the dry seasons. Iron contents varies from 0.10 to $1.39 \mathrm{mg} /$ $\mathrm{L}$ (mean $0.43 \mathrm{mg} / \mathrm{L}$ ) in the wet seasons and 0.12 to $3.61 \mathrm{mg} / \mathrm{L}$ (mean $0.81 \mathrm{mg} / \mathrm{L}$ ) in the dry seasons with most sources exceeding WHO (2004) limit $(0.30 \mathrm{mg} / \mathrm{L})$ for drinking water. It is obvious that in the wet season $54.4 \%$ of surface water sources have $\mathrm{Fe}$ content below the maximum permissible limit while in the dry season, $\mathrm{Fe}$ content increases to well above this limit for $94.4 \%$ surface water sources, mainly due to the reduction in water volume. $85.8 \%$ of sources in the dry seasons and $45.8 \%$ of sources in the wet seasons show $\mathrm{Fe}$ content in the range of $0.3-1.5 \mathrm{mg} / \mathrm{L}$. Manganese commonly coexists with iron in water. However, where this occurs, the concentrations of iron are generally greater because iron has a greater crustal abundance. The surface water samples of the study area show $\mathrm{Mn}$ content in the range of BDL $-0.14 \mathrm{mg} / \mathrm{L}$ (mean $0.04 \mathrm{mg} / \mathrm{L}$ ) in the wet seasons and BDL $-0.20 \mathrm{mg} / \mathrm{L}$ (mean $0.08 \mathrm{mg} / \mathrm{L}$ ) in the dry seasons. Only $8.6 \%$ of the samples in the wet seasons and $34.3 \%$ of samples in the dry seasons have $\mathrm{Mn}$ above the permissible limit of $0.10 \mathrm{mg} / \mathrm{L}$ (WHO 1984). In this work, Ni contents spread from $\mathrm{BDL}$ to $0.12 \mathrm{mg} / \mathrm{L}$ (mean $0.04 \mathrm{mg} / \mathrm{L}$ ) in the wet seasons and from BDL to $0.20 \mathrm{mg} / \mathrm{L}$ (mean $0.08 \mathrm{mg} / \mathrm{L}$ ) in the dry seasons. $60.1 \%$ of water samples during the wet season and $80.1 \%$ of water samples during the dry season show Ni content above the permissible limit of $0.02 \mathrm{mg} / \mathrm{L}$. Surfacewater sources have been found to have $\mathrm{Ni}$ content in the range of BDL $-0.12 \mathrm{mg} / \mathrm{L}$ in the wet seasons and from BDL $-0.21 \mathrm{mg} / \mathrm{L}$ in the dry seasons. $91.5 \%$ of sources have comparatively higher nickel concentrations in the dry season than in the wet season. In this work, the concentration of $\mathrm{Pb}$ was in the range of $\mathrm{BDL}-0.30 \mathrm{mg} / \mathrm{L}$ (mean $0.11 \mathrm{mg} / \mathrm{L}$ ) in the dry seasons and BDL $-0.17 \mathrm{mg} / \mathrm{L}$ (mean $0.06 \mathrm{mg} / \mathrm{L}$ ) in the wet seasons. Most of the values exceed the maximum permissible limit of $0.05 \mathrm{mg} / \mathrm{L}$ for drinking water (WHO 2004). In this study, almost all the surface water sources have higher $\mathrm{Pb}$ content in the dry season than in the wet season. $54.4 \%$ of the surface water samples have $\mathrm{Pb}$ above the permissible limit of $0.05 \mathrm{mg} / \mathrm{L}$ (WHO 1984) during the rainy season while in the dry season, $85.8 \%$ of the surface water sources show $\mathrm{Pb}$ above the limit corresponding to the low $\mathrm{pH}$ of the sources. Zinc shows a significant content in the surface waters from BDL $-0.10 \mathrm{mg} / \mathrm{L}$ (mean $0.02 \mathrm{mg} / \mathrm{L}$ ) in the wet seasons and BDL $-0.11 \mathrm{mg} / \mathrm{L}$ (mean $0.04 \mathrm{mg} / \mathrm{L}$ ) in the dry seasons. However, even the highest values of $\mathrm{Zn}$ measured in this work are far below the guideline value of $3 \mathrm{mg} / \mathrm{L}$ (WHO 2004). River water samples have low $\mathrm{Zn}$ content compared to that of pond water sources ranging from BDL $-0.05 \mathrm{mg} / \mathrm{L}$ in both the wet and the dry seasons.

\section{Pearson-correlation matrix}

It is a simplified statistical tool to show the degree of dependency of one variable to the other (Belkhiri et al. 2010). The generated correlation values are complied in the Tables 1 and 2. The poor correlation between As and $\mathrm{Fe}$ in both the seasons may be caused by the removal of $\mathrm{Fe}$ as $\mathrm{FeCO}_{3}$ solids (Lee et al. 2010). It may be concluded that As could be released into water due to reductive dissolution of 
Table 1 Correlation matrix of the trace metals in the wet season (taking Wavg)

\begin{tabular}{|c|c|c|c|c|c|c|c|c|c|c|}
\hline & As & $\mathrm{Cd}$ & Co & $\mathrm{Cu}$ & $\mathrm{Cr}$ & $\mathrm{Fe}$ & $\mathrm{Mn}$ & $\mathrm{Ni}$ & $\mathrm{Pb}$ & $\mathrm{Zn}$ \\
\hline As & 1.00 & 0.06 & 0.34 & -0.03 & -0.34 & 0.04 & -0.14 & -0.31 & 0.32 & 0.14 \\
\hline $\mathrm{Cd}$ & 0.06 & 1.00 & 0.28 & -0.20 & 0.00 & -0.05 & 0.15 & 0.39 & 0.38 & -0.01 \\
\hline Co & 0.34 & 0.28 & 1.00 & -0.03 & 0.27 & 0.03 & 0.13 & 0.08 & 0.44 & 0.19 \\
\hline $\mathrm{Cu}$ & -0.03 & -0.20 & -0.03 & 1.00 & 0.13 & 0.47 & 0.38 & 0.29 & 0.19 & 0.00 \\
\hline $\mathrm{Cr}$ & -0.34 & 0.00 & 0.27 & 0.13 & 1.00 & 0.16 & 0.09 & 0.29 & 0.11 & 0.14 \\
\hline $\mathrm{Fe}$ & 0.04 & -0.05 & 0.03 & 0.47 & 0.16 & 1.00 & 0.05 & 0.21 & 0.01 & 0.48 \\
\hline $\mathrm{Mn}$ & -0.14 & 0.15 & 0.13 & 0.38 & 0.09 & 0.05 & 1.00 & 0.34 & 0.28 & -0.12 \\
\hline $\mathrm{Ni}$ & -0.31 & 0.39 & 0.08 & 0.29 & 0.29 & 0.21 & 0.34 & 1.00 & 0.11 & 0.21 \\
\hline $\mathrm{Pb}$ & 0.32 & 0.38 & 0.44 & 0.19 & 0.11 & 0.01 & 0.28 & 0.11 & 1.00 & 0.20 \\
\hline $\mathrm{Zn}$ & 0.14 & -0.01 & 0.19 & 0.00 & 0.14 & 0.48 & -0.12 & 0.21 & 0.20 & 1.00 \\
\hline
\end{tabular}

Bold values indicate good co-relations

Table 2 Correlation matrix of the trace metals in the dry season (taking Davg)

\begin{tabular}{lrrrrrrrrrr}
\hline & \multicolumn{1}{l}{$\mathrm{As}$} & \multicolumn{1}{c}{$\mathrm{Cd}$} & $\mathrm{Co}$ & $\mathrm{Cu}$ & $\mathrm{Cr}$ & $\mathrm{Fe}$ & $\mathrm{Mn}$ & $\mathrm{Ni}$ & $\mathrm{Pb}$ \\
\hline $\mathrm{As}$ & 1.00 & 0.08 & 0.09 & 0.32 & -0.18 & 0.18 & 0.37 & 0.08 & -0.02 & -0.19 \\
$\mathrm{Cd}$ & 0.08 & 1.00 & 0.00 & 0.02 & 0.05 & -0.25 & 0.01 & 0.14 & 0.14 & -0.22 \\
$\mathrm{Co}$ & 0.09 & 0.00 & 1.00 & -0.17 & 0.16 & -0.20 & -0.06 & -0.24 & 0.23 & -0.34 \\
$\mathrm{Cu}$ & 0.32 & 0.02 & -0.17 & 1.00 & -0.14 & 0.03 & 0.02 & 0.28 & 0.18 & -0.13 \\
$\mathrm{Cr}$ & -0.18 & 0.05 & 0.16 & -0.14 & 1.00 & -0.03 & -0.04 & 0.06 & -0.19 & 0.18 \\
$\mathrm{Fe}$ & 0.18 & -0.25 & -0.20 & 0.03 & -0.03 & 1.00 & 0.05 & 0.15 & -0.16 & 0.43 \\
$\mathrm{Mn}$ & 0.37 & 0.01 & -0.06 & 0.02 & -0.04 & 0.05 & 1.00 & 0.11 & 0.04 & 0.00 \\
$\mathrm{Ni}$ & 0.08 & 0.14 & -0.24 & 0.28 & 0.06 & 0.15 & 0.11 & 1.00 & 0.28 & 0.27 \\
$\mathrm{~Pb}$ & -0.02 & 0.14 & 0.23 & 0.18 & -0.19 & -0.16 & 0.04 & 0.28 & 1.00 & -0.01 \\
$\mathrm{Zn}$ & -0.19 & -0.22 & -0.34 & -0.13 & 0.18 & 0.43 & 0.00 & 0.27 & -0.01 & 1.00 \\
\hline
\end{tabular}

$\mathrm{MnO}(\mathrm{OH})$ or $\mathrm{FeO}(\mathrm{OH})$ as bacteria oxidizes organic matter to gain energy (Ohno et al. 2005; Shamsudduha et al. 2008). The existence of positive correlation between iron and manganese in both the season suggests natural occurrence of these two metals from dissolution of soils, rocks, and minerals. A significant positive correlation is found to exist between (1) $\mathrm{Cu}$ and $\mathrm{Fe}(r$ 0.47) (2) $\mathrm{Co}$ and $\mathrm{Pb}(r 0.44)$ and (3) Fe and $\mathrm{Zn}(r$ 0.48) signifying their similar source of geogenic origin and mobility. Pearson correlation analysis also shows that most of the trace metals are weakly and moderately correlated to each other at $r<0.05$ level.

\section{Multivariate statistical analysis}

\section{Raw data treatment}

To confirm the normal distribution, of each variable required for multivariate statistical analysis is checked by analyzing kurtosis and skewness statistical tests (Lattin et al. 2003). The original data shows a wide range of skewness values indicating that the data are far from normal distribution. Since most of the values of kurtosis and skewness are $>0$, the raw data of all variables are transformed in the form $x^{\prime}=\log 10(x)$. After transformation, the skewness values range from -1.459 to 1.191 in the wet season and -0.826 to 3.346 in the dry season while kurtosis values ranged from -1.777 to 2.155 in the wet season and -1.205 to 2.838 in the dry season, respectively, indicating that all the data are in normal distribution or close to normal distribution. KMO is a measure of sampling adequacy for the proportion of common variance caused by underlying factors. The value of KMO close to 1.0 generally indicates that principal component analysis or factor analysis may be useful, which is the case in this study: KMO 0.44 in the wet season and 0.46 in the dry season. Bartlett's test of sphericity indicates whether correlation matrix is an identity matrix, i.e., the variables are unrelated (Shrestha and Kazama 2007). The high significance level $(>0.05)$ in this study indicates the presence of close relationships among the variables in the wet season (0.39) and strongly in the dry season (0.62). KMO and Bartlett's tests 
Table 3 KMO and Bartlett's test of sphericity (taking Wavg and Davg for respective seasons)

\begin{tabular}{llll}
\hline KMO \& Bartlett's Test & Wet season & Dry season \\
\hline Kaiser-Meyer-Olkin Measure of sampling adequacy & 0.44 & 0.46 \\
Bartlett's test of sphericity & Approx. Chi-square & 46.96 & 41.47 \\
& df & 45 & 45 \\
& Sig. & 0.392 & 0.622 \\
\hline
\end{tabular}

are presented in the Table 3 . The generation of positive skewness and kurtosis values demonstrates asymmetric distribution of almost all the heavy elements in the studied basin (Fig. 1).

\section{Principal component analysis}

Principal component analysis (PCA) is a multivariate statistical technique used for data reduction and for deciphering patterns within large sets of data (Farnham et al. 2003). Due to the variation of concentration, PCA is applied to the correlation matrix of 10 trace metallic variables. The eigenvectors of the correlation matrix are principal components and each original observation is converted to principal component score by projecting it onto the principal axes (Chen et al. 2007). The elements of the eigenvectors that are used to compute the scores of the observations are called principal component loadings. Typically, the raw data matrix can be reduced to two or more principal component loadings that account for the majority of the variance. The first principal component loading explains the most variance and each subsequent component explains progressively less. As a result, a small number of factors usually account for approximately the same amount of information as the much larger set of the original observations do. In this context, using the varimax normalization (Kaiser 1960) five principle components (PC) were extracted for the wet season and four factors for the dry season for the studied database and they are presented in the Tables 4 and 5. The results shows that the PC having eigen values more than 1 account for $71.45 \%$ of the total variance in the wet season and $61.90 \%$ of total variance for the dry season which is quite useful to identify the main sources of variation in the hydrochemistry of trace metals in all the seasons (Figs. 2, 3 and 4). PC 1 defines $21.1 \%$ of variance in the wet season with strong positive loadings $(>0.50)$ of $\mathrm{Co}$ and $\mathrm{Ni}$ while in the dry season it accounts $19.79 \%$ of the total variance with strong positive loading of As, Mn and $\mathrm{Zn}$. Thus, PC 1 can be attributed increasing urban activities as well as increasing household and industrial wastes in the catchment area. In the wet season trace elements with positive PC 1 loadings typically occur as soluble oxyanion in oxidizing waters, whereas $\mathrm{Mn}$ and Cr with negative PC 1 loadings were generally more soluble within oxygen depleted groundwater. The solubility of $\mathrm{Mn}$ as $\mathrm{Mn}^{2+}$, is very high in low $\mathrm{pH}$ (reducing) waters, and much lower in oxidizing waters because manganese precipitates as $\mathrm{Mn}(\mathrm{IV})$-oxide scavenging other trace elements like $\mathrm{Co}, \mathrm{Pb}, \mathrm{Zn}, \mathrm{Cu}$ and $\mathrm{Ni}$ from solution in more oxidizing waters (Farnham et al. 2003). Arsenic, the redox sensitive element, is commonly more soluble in oxidized groundwater occurring as oxyanion $\mathrm{AsO}_{4}{ }^{2-}$ or $\mathrm{H}_{2} \mathrm{AsO}_{4}{ }^{-}$. However, in reducing waters, arsenic tends to be incorporated in insoluble minerals (Langmuir 1997; Welch and Lico 1998). PC 2 with $15 \%$ of the total variance in both the seasons loads positive scores of $\mathrm{Cd}$, $\mathrm{Co}, \mathrm{Cr}, \mathrm{Pb}$ and $\mathrm{Zn}$ in the wet season and $\mathrm{Cd}, \mathrm{Co}, \mathrm{Cu}, \mathrm{Fe}$ and $\mathrm{Mn}$ in the dry season. The enrichment of these trace metals in water may be due to soil leaching and chemical weathering linking particular geology of the plain (Simeonova et al. 2003; Zorer et al. 2008). These elements are most often found in crustal components (Zelenka et al. 1994; Atgin 2000; Kumar et al. 2001) and hence PC 2 may be ascribed as geogenic factor influencing the trace metal distribution in the surfacewater sources. The negative loadings of $\mathrm{Fe}$ and $\mathrm{Mn}$ in the monsoon season has been attributed to the dilution effect of the high rainfall in the basin and consequent increased flow of water into the surface water sources (Sharma and Subramanian 2010). PC 3 showing $\sim 14 \%$ of the total variance in both the season loads high positive scores of $\mathrm{Cu}, \mathrm{Ni}, \mathrm{Pb}, \mathrm{Zn}$ in the wet season while $\mathrm{As}, \mathrm{Cd}, \mathrm{Fe}, \mathrm{Pb}$ and $\mathrm{Zn}$ in the dry season. As agriculture is the mainstay of a large majority of the population of the study area, the extensive cultivation and wide use of chemical fertilizer may have added these metal ions into the surface water sources through surface runoff (Chatterjee et al. 2009; Toor et al. 2010) in both the seasons. Having positive loadings of micronutrient $\mathrm{Zn}$ in both the seasons, the surface water sources indicate the $\mathrm{Zn}$ enrichment of the basin and thus attribute their suitability for irrigation purposes. PC 4, which accounts for $11 \%$ of the total variance in the dry season and same in the wet season, shows positive loadings of all metals except a few (Fe and $\mathrm{Pb}$ in the wet season, $\mathrm{Cu}$ and $\mathrm{Mn}$ in the dry season) 


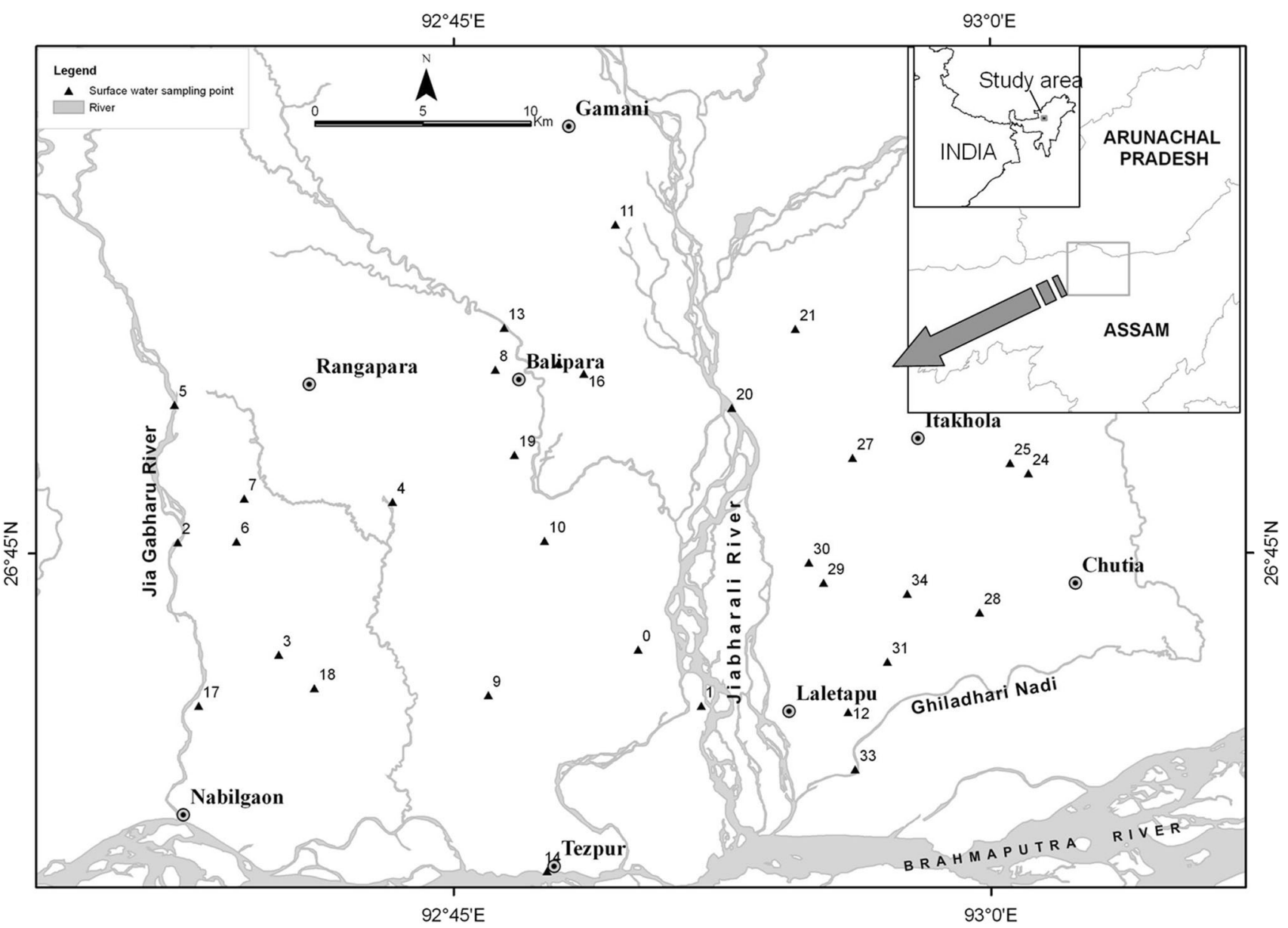

Fig. 1 Locations of surfacewater sampling points in Jia Bharali lower catchment and adjoining region

Table 4 Principal component analysis in the wet season (taking Wavg)

\begin{tabular}{|c|c|c|c|c|c|c|}
\hline Parameters & PC 1 & PC 2 & PC 3 & PC 4 & PC 5 & Communalities \\
\hline As & 0.461 & -0.523 & -0.198 & 0.154 & 0.298 & 0.639 \\
\hline $\mathrm{Cd}$ & 0.371 & 0.537 & & 0.287 & 0.297 & 0.598 \\
\hline Co & 0.722 & 0.259 & -0.237 & 0.219 & & 0.696 \\
\hline $\mathrm{Cu}$ & & -0.123 & 0.812 & 0.242 & 0.348 & 0.863 \\
\hline $\mathrm{Cr}$ & -0.634 & 0.411 & & 0.389 & 0.4 & 0.882 \\
\hline $\mathrm{Fe}$ & -0.644 & & 0.196 & & -0.438 & 0.646 \\
\hline $\mathrm{Mn}$ & -0.12 & -0.697 & & 0.194 & & 0.545 \\
\hline $\mathrm{Ni}$ & 0.531 & -0.221 & 0.633 & -0.188 & & 0.769 \\
\hline $\mathrm{Pb}$ & 0.29 & 0.16 & 0.254 & 0.576 & -0.599 & 0.865 \\
\hline $\mathrm{Zn}$ & 0.164 & 0.44 & 0.274 & -0.586 & & 0.642 \\
\hline Eigen values & 2.105 & 1.568 & 1.335 & 1.112 & 1.024 & \\
\hline Total variance $(\%)$ & 21.05 & 15.68 & 13.35 & 11.12 & 10.24 & \\
\hline Cumulative variance $(\%)$ & 21.05 & 36.74 & 50.09 & 61.21 & 71.45 & \\
\hline
\end{tabular}

representing the erosion effect during cultivation of soil and associated organic matter in the study area (Kazama and Yoneyama 2002; Fukasawa 2005). PC 5 accounts for $10 \%$ only in the wet season and shows positive loadings for $\mathrm{As}, \mathrm{Cd}, \mathrm{Cu}$, and $\mathrm{Cr}$. Thus, PC 5 in the wet season receives contribution from road traffic runoff due to increased urbanization and industrialization of the studied river basin. 
Table 5 Principal component analysis in the dry season (taking Davg)

\begin{tabular}{|c|c|c|c|c|c|}
\hline Parameters & PC 1 & PC 2 & PC 3 & PC 4 & Communalities \\
\hline As & 0.537 & 0.302 & 0.455 & 0.286 & 0.667 \\
\hline $\mathrm{Cd}$ & -0.51 & 0.347 & 0.361 & 0.408 & 0.677 \\
\hline Co & -0.574 & 0.19 & & 0.404 & 0.533 \\
\hline $\mathrm{Cu}$ & 0.222 & 0.516 & -0.222 & -0.599 & 0.725 \\
\hline $\mathrm{Cr}$ & -0.110 & & -0.736 & 0.322 & 0.657 \\
\hline $\mathrm{Fe}$ & -0.592 & 0.316 & 0.159 & -0.305 & 0.569 \\
\hline $\mathrm{Mn}$ & 0.521 & 0.258 & -0.319 & 0.439 & 0.632 \\
\hline $\mathrm{Ni}$ & 0.186 & -0.562 & -0.200 & & 0.397 \\
\hline $\mathrm{Pb}$ & -0.151 & -0.733 & 0.382 & & 0.708 \\
\hline $\mathrm{Zn}$ & 0.601 & & 0.504 & & 0.625 \\
\hline Eigen values & 1.978 & 1.542 & 1.499 & 1.170 & \\
\hline Total variance $(\%)$ & 19.79 & 15.42 & 14.99 & 11.70 & \\
\hline Cumulative variance $(\%)$ & 19.79 & 35.21 & 50.19 & 61.90 & \\
\hline
\end{tabular}
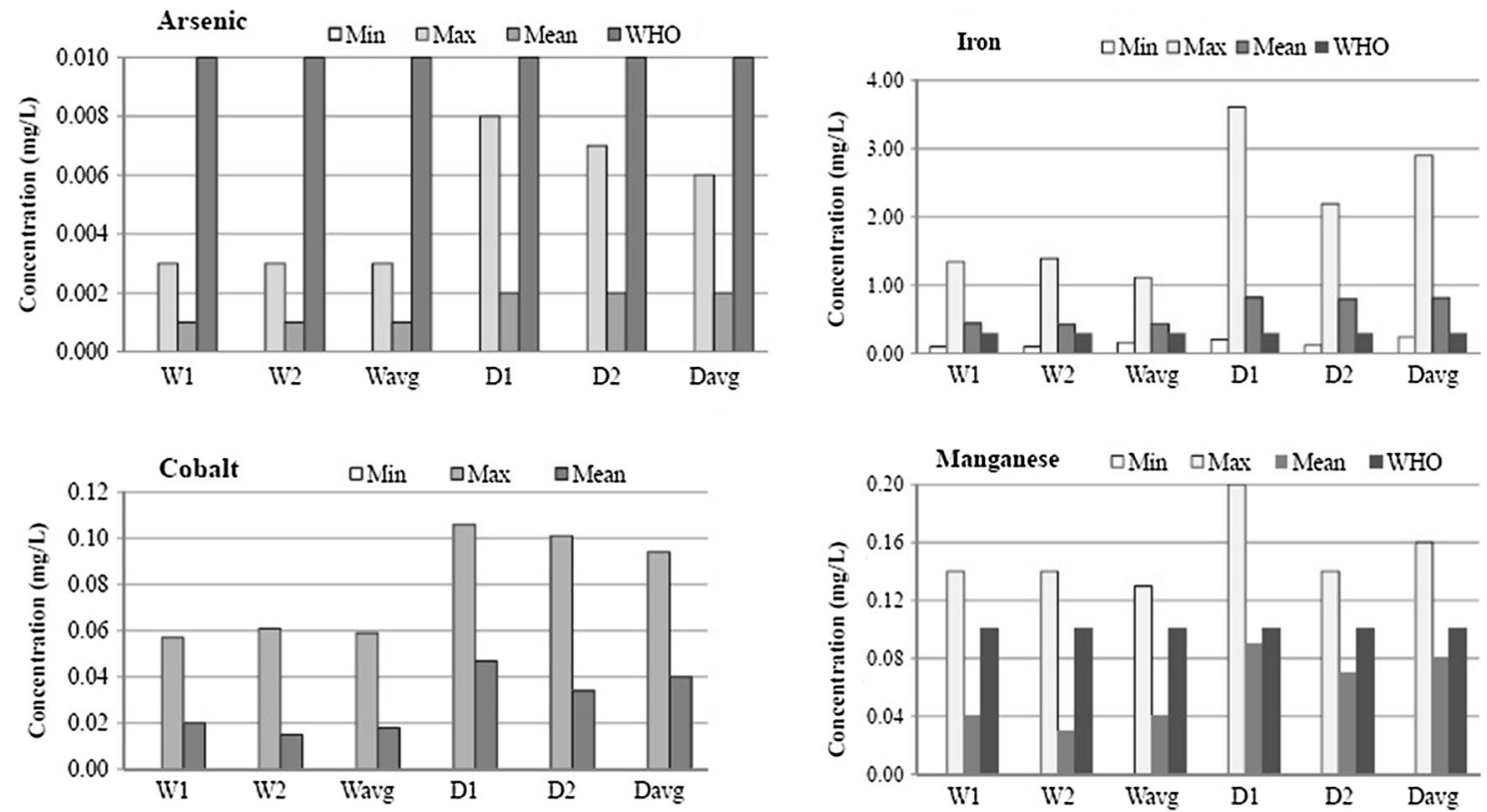

Fig. 2 Seasonal distribution of As, Fe, Mn and Co $(\mathrm{mg} / \mathrm{L})$ in the selected surfacewater sources

\section{Cluster analysis}

Cluster analysis comprises a series of multivariate methods which are used to find true groups of data. In clustering, similar objects are grouped into the same class (Danielsson et al. 1999). Hierarchical cluster analysis is the most widely applied techniques to detect similar and dissimilar groups between the sampling sites (Shrestha and Kazama 2007). Hierarchical clustering joins the most similar observations, and then successively the next most similar observations.
The levels of similarity at which observations are merged are used to construct a dendrogram. The datasets generated in this study was treated by the Ward's method of linkage with squared Euclidean distance as a measure of similarity. The dendrogram of sites obtained by Ward's method in $\mathrm{Jia}$ - Bharali river basin is shown in Figs. 5 and 6. On the basis of dendrogram 10 variables can be grouped into two main clusters in both the seasons. First group includes $\mathrm{Cu}$, $\mathrm{Cd}, \mathrm{Pb}, \mathrm{Co}, \mathrm{Cr}, \mathrm{Ni}, \mathrm{Zn}, \mathrm{Mn}$ and $\mathrm{Fe}$ while group 2 includes only one element Arsenic. These differences in spatial 

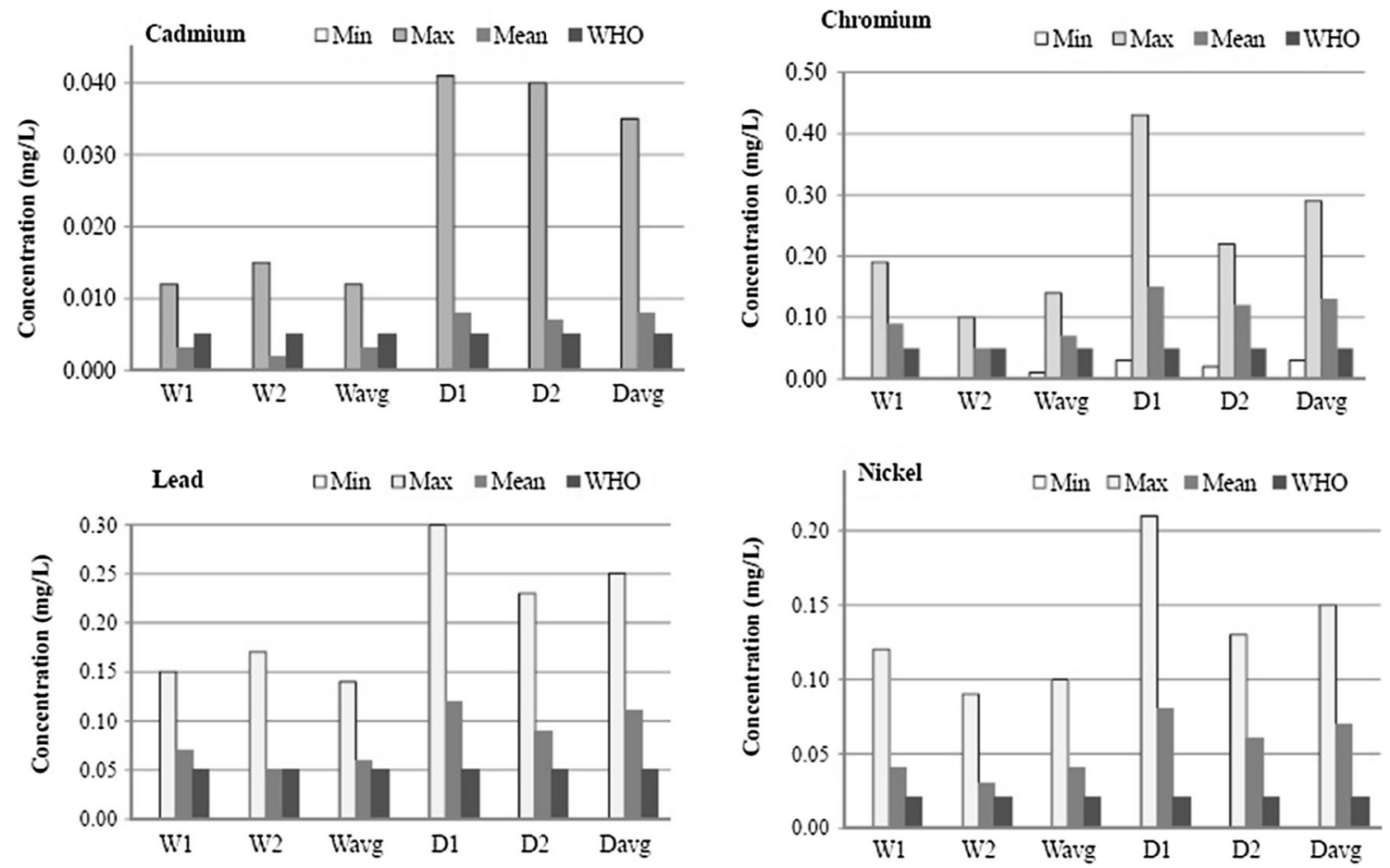

Fig. 3 Seasonal distribution of $\mathrm{Cd}, \mathrm{Cr}, \mathrm{Pb}$ and $\mathrm{Ni}(\mathrm{mg} / \mathrm{L})$ in the surfacewater sources
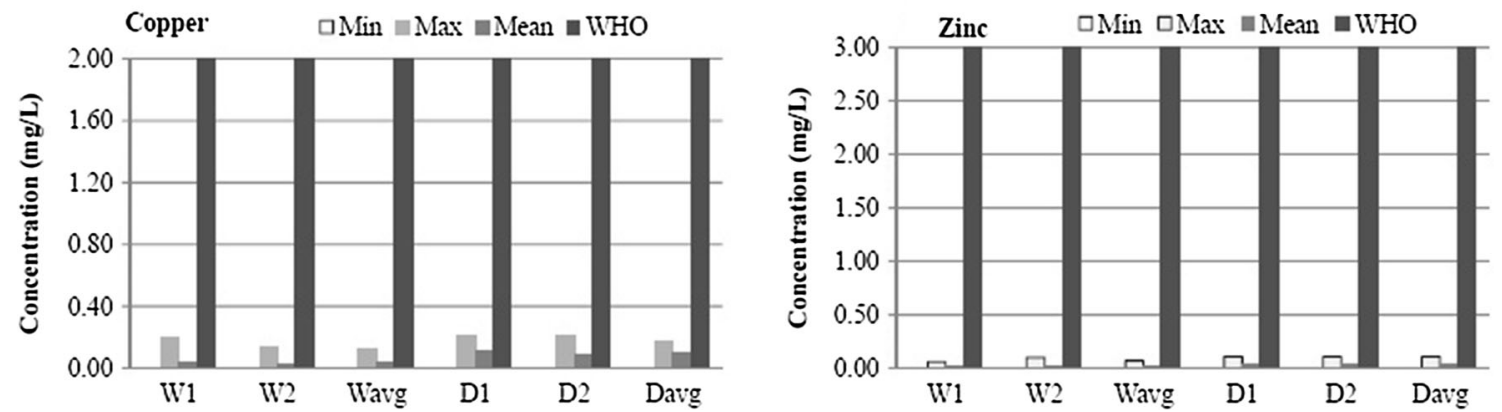

Fig. 4 Seasonal distribution of $\mathrm{Cu}$ and $\mathrm{Zn}(\mathrm{mg} / \mathrm{L})$ in the surfacewater sources

Fig. 5 Dendrogram showing the relationship among the variables in the wet season
H I E R A R C H I C \& L C L U S T E R A N \& L Y S I S Dendrogram using Ward Method

Rescaled Distance Cluster Combine

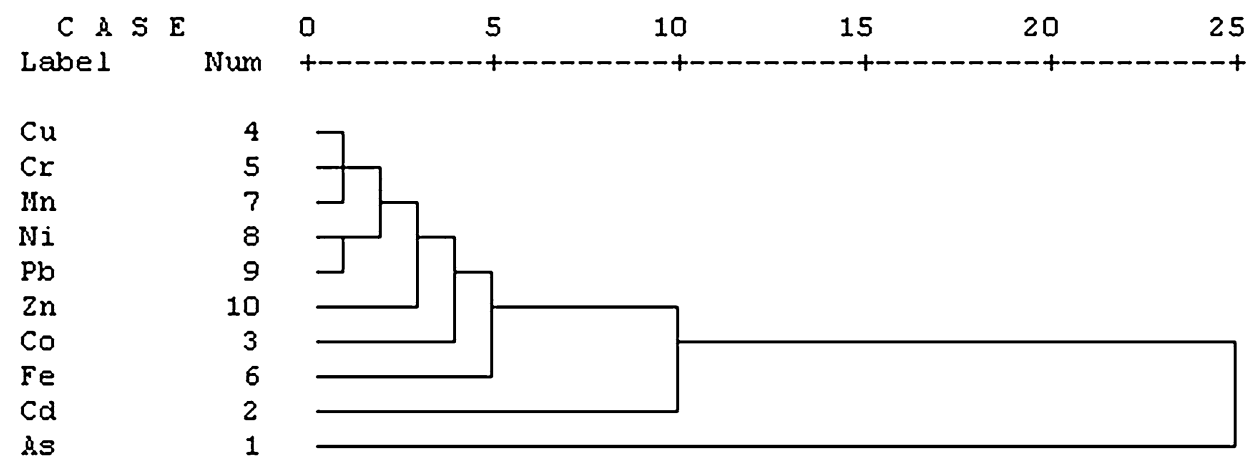


Fig. 6 Dendrogram showing the relationship among the variables in the dry season
H I E R A R C H I C A L C L U S T E R A N A L Y S I S

Dendrogram using ward Method

Rescaled Distance Cluster Combine

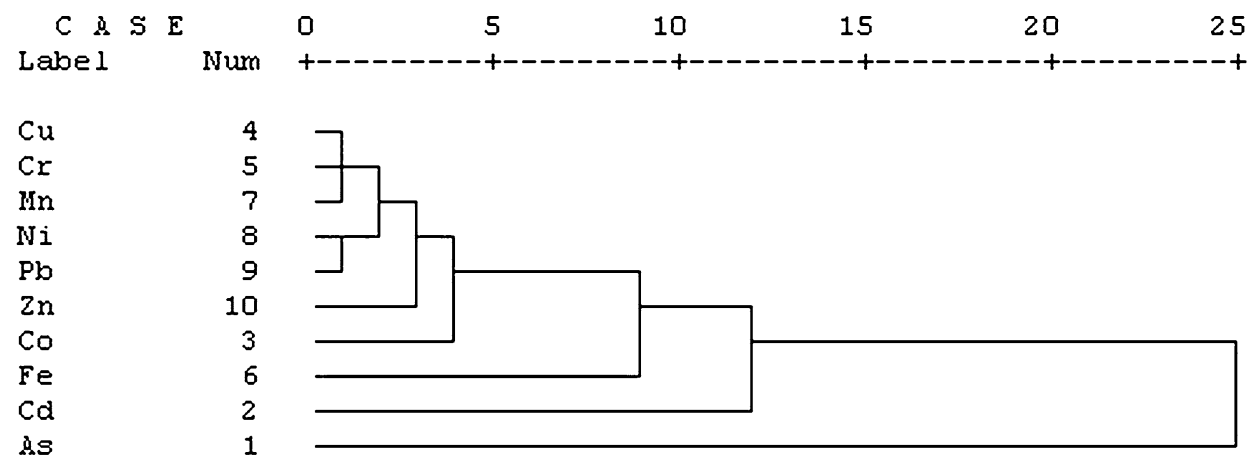
s distribution could be attributed to differences in the behaviour and reactions of these metals in water that affect their mobility. For example, $\mathrm{Cd}$ is highly mobile compared to $\mathrm{Pb}$ (Alloway 1995) and can affect the concentration and dispersion of $\mathrm{Cd}$ in surfacewater. Chemical leaching and precipitation have been found to be the major contributors to heavy metal contamination in soils and sediments (Avil et al. 2005) and consequently surfacewater. The study area is a rainforest area with very high annual rainfall (Jain et al. 2007). Therefore, it can be deduced that chemical leaching, weathering and rainfall may be the major contributory factors to heavy metal contamination of the sampled water in the study area.

\section{Conclusion}

The hydrochemical and multivariate analysis of surface water samples reveals the present status of surface water quality with respect to the trace metals in and around the Jia Bharali river basin of North Brahmaputra Plain, India. The study shows that the analysis of hydrochemical data using the multivariate statistical techniques such as principal component analysis and cluster analysis gives some information not available at first observation. Different statistical estimations, viz. standard deviation, variance, skewness, and kurtosis, performed for each metallic constituent reveals their normal and asymmetric distribution in the river catchment. All the water samples analyzed in the present investigation are contaminated with $\mathrm{Fe}, \mathrm{Pb}, \mathrm{Cr}$ and partially with $\mathrm{Mn}$, Ni lead, and $\mathrm{Cd}$. Apart from the geogenic sources, anthropogenic sources linked to extensive tea cultivation and other which, however, needs to be ascertained with further close spaced sample analysis.
Acknowledgments The present study was carried out under the Department of Science and Technology, Govt. of India sponsored project SR/S4/ES-21/BRAHMAPUTRAII/2005/(P-1).

Open Access This article is distributed under the terms of the Creative Commons Attribution 4.0 International License (http:// creativecommons.org/licenses/by/4.0/), which permits unrestricted use, distribution, and reproduction in any medium, provided you give appropriate credit to the original author(s) and the source, provide a link to the Creative Commons license, and indicate if changes were made.

\section{References}

Ahmed E (2001) Geomorphology. Kalyani Publishers, New Delhi Alloway BJ (1995) Heavy metals in soils. Blackie Academic and Professional, London

APHA, AWWA (American Public Health Association) (1998) Standard methods for the examination of water and wastewater. American Public Health Association, Washington

Atgin RS 2000. Investigation of the sediments of Izmir Bay: trace elements, M.Sc. Thesis, Middle East Technical University, Ankara, p. 156

Avil PF, Oliveira JMS, da Silva EF, Fonseca EC (2005) Geochemical signatures and mechanisms of trace elements dispersion in the area of the Vale das Gatas mine (Northern Portugal). J Geochem Explor 85(1):17-29

Belkhiri L, Boudoukha A, Mouni L (2010) A multivariate Statistical analysis of groundwater chemistry data. Int $\mathrm{J}$ Environ Res 5(2):537-544

Chakrapani GJ (2005) Major and trace element geochemistry in upper Ganga River in the Himalayas, India. Environ Geol 48(22):189-201

Chatterjee SK, Bhattacharjee I, Chandra G (2009) Water quality assessment near an industrial site of Damodar River, India. Environ Monit Assess 161:177-189

Chen A, Jiu J, Jiao A, Jianmin Huang B, Runquie Huang B (2007) Multivariate statistical evaluation of trace elements in groundwater in a coastal area in Shenzhen China Kouping. Environ Pollut 147:771-780 
Danielsson A, Cato I, Carman R, Rahm L (1999) Spatial clustering of metals in the sediments of the Skagerrak/Kattegat. Appl Geochem 14:689-706

Farnham IM, Johannesson KH, Singh AK, Hodge VF, Stetzenbach KJ (2003) Factor analytical approaches for evaluating groundwater trace element chemistry data. Anal Chimica Acta 490:123-138

Fukasawa E (2005) Determination of origin of nitrate nitrogen in Fuefuki river using stable isotope method. Bachelor thesis, Department of Eco social System Engineering, University of Yamanashi, Japan (in Japanese)

Goswami DC (1985) Brahmaputra river, Assam, India: physiography, basin denudation and channel aggradation. Water Resour Res 21:959-978

Helena B, Pardo B, Vega M, Barrado E, Fernandez JM, Fernandez L (2000) Temporal evolution of groundwater composition in an alluvial aquifer (Pisuerga River, Spain) by principal component analysis. Water Res 34(3):807-816

Jain SK, Agarwal PK, Singh VP (2007) Hydrology and water resources of India. Springer, Dordrecht (13-978-1-4020-5180-7, e-book)

Jameel AA, Hussain AZ (2007) Assessment of ground water on banks of Uyyakondan channel of River Cauvery at Tiruchirappalli. Indian J Environ Prot 27(8):713-716

Kaiser HF (1960) The application of electronic computers to factor analysis. Educ Psychol Measur 20:141-151

Kazama F, Yoneyama M (2002) Nitrogen generation in the Yamanashi prefecture and its effects on the groundwater pollution. Int Environ Sci 15(4):293-298 (in Japanese)

Khound Nayan J, Phukon P, Bhattacharyya KG (2013) Assessment of dissolved trace metals in the shallow aquifers of the Jia-Bharali River Basin, Assam, India. J Geol Soc India 82:162-168

Kumar AV, Patil RS, Nambi KSV (2001) Source apportionment of suspended particulate matter at two traffic junctions in Mumbai, India. Atmos Environ 35:4245-4251

Langmuir D (1997) Aqueous environmental geochemistry. PrenticeHall, New Jersey, p 600

Lattin J, Carroll D, Green P (2003) Analyzing multivariate data. Duxbury press, New York

Lee KY, Kim KW, Kim SO (2010) Geochemical and microbial effects on the mobilization of arsenic in mine tailing soils. Environ Geochem Health 32:31-44

Meglen RR (1992) Examining large databases: a chemometric approach using principal component analysis. Mar Chem 39:217-237

Merian E (ed) (1991) Metals and their compounds in the environment, occurrence, analysis and biological relevance. UCH, Weinheim

Nandy DR, Mullick BB, Basu Chowdhury S, Murthy MVN (1971) Geology of the NEFA Himalayas. Paper presented at the seminar on recent geological studies in the Himalayas, Calcutta, Oct 1971

Ogwoeleka TC (2015) Use of multivariate statistical techniques for the evaluation of temporal and spatial variations in water quality of Kaduna River, Nigeria. Environ Monit Assess. doi:10.1007/ s10661-015-4354-4

Ohno K, Furukawa A, Hayashi K, Kamei T, Magara Y (2005) Arsenic contamination of groundwater in Nawabganj, Bangladesh, focusing on the relationship with other metals and ions. Water Sci Technol 52:87-94
Pazand K (2016) Geochemistry and multivariate statistical analysis for fluoride occurrence in groundwater in the Kuhbanan basin, Central Iran, Model. Earth Syst Environ 2:72. doi:10.1007/ s40808-016-0127-5

Phukon P, Machahary R (2011) Bankline migration of the Jiabharali river, North Brahmaputra Plain, Assam'. Memoir Geol Soc India (77):547-557

Qian J, Wang L, Ma L, Lu YH, Zhao w, Zhang Y (2016) Multivariate statistical analysis of water chemistry in evaluating groundwater, geochemical evolution and aquifer connectivity near a large coal mine, Anhui, China. Environ Earth Sci 75-747:1066. doi:10. 1007/s1-016-5541-5

Shamsudduha M, Uddin A, Saunders JA, Lee MK (2008) Quaternary stratigraphy, sediment characteristics and geochemistry of arsenic contaminated alluvial aquifers in the Ganges-Brahmaputra floodplain in central Bangladesh. J Contam Hydrol 99:112-136

Sharma SK, Subramanian V (2010) Source and distribution of trace metals and nutrients in Narmada and Tapti river basins, India. Environ Earth Sci. doi:10.1007/s12665-010-0452-3

Shrestha S, Kazama F (2007) Assessment of surface water quality using multivariate statistical techniques: a case study of the Fuji river basin, Japan. Environ Model Softw 22:464-475

Simeonova V, Stratisb JA, Samarac C, Zachariadisb G, Voutsac D, Anthemidis A, Sofonioub M, Kouimtzisc Th (2003) Assessment of the surface water quality in Northern Greece. Water Res 37:4119-4124

Singh KP, Malik A, Sinha S (2005) Water quality assessment and apportionment of pollution sources of Gomti River (India) using multivariate statistical techniques-a case study. Anal Chim Acta 538:355-374

Thornbury WD (1989) Principles of geomorphology, 2nd edn. Wiley Eastern Ltd., New Delhi

Toor AS, Khurana MPS, Sidhu BS, Khera JS, Brar KK (2010) Suitability of village pond waters for irrigation-a case study from district Ludhiana, India. Environ Monit Assess. doi:10. 1007/s10661-010-1355-1

Viswanathan TV, Chakrabarti C (1977) The Jia Bhareli Basin: fluvial processes, geomprphology and geology. In: Contributions to geomorphology and geohydrology of the Brahmaputra Valley, Geological Survey of India Miscellaneous Publication No. 32

Welch AH, Lico MS (1998) Factors controlling As and U in shallow groundwater, southern Carson Desert, Nevada. Appl Geochem 13:521-539

Wenning RJ, Erickson GA (1994) Interpretation and analysis of complex environmental data using chemometric methods. Trends Anal Chem 13:446-457

WHO (1984) Guidelines for drinking water quality, vol 2 Health criteria and other supporting information. WHO, Geneva, p 335

WHO (2004) Guidelines for drinking-water quality (Vol 1), 3rd edn. World Health Organization, Geneva

Zelenka MP, Wilson WE, Chow JC, Lioy PJ (1994) A combined TTFA/CMB receptor modeling approach and its application to air pollution sources in China. Atmos Environ 28(8):1425-1435

Zorer OS, Ceylan H, Dogru M (2008) Assessments of some trace heavy metals and radioactivity concentration in water of Bendimahi River Basin (Van, Turkey). Environ Monit Assess 147:183-190 